account of his discovery, in the course of miscellaneous reading, of a series of articles describing British watermites which appeared in Science Gossip in 1899 and 1900. The author was C. D. Soar, and Williamson, finding that he could easily identify from the detailed descriptions the water-mites he began to collect, got in touch with Soar, so commencing a friendship which lasted until Soar's death, almost forty years later. The contact was in a way a turning-point in his life, for the enthusiasm of one amateur stimulated the other, and Williamson's spare time now became devoted to collecting, identifying and recording hydrachnids.

Williamson published a series of papers, generally in Scottish scientific journals, on his own eollecting in various parts of Scotland, identified the collections made during Murray and Pullar's "Survey of Scottish Fresh-water Lochs", revised the early Berwickshire list of Johnston and Dalyell's "Scottish Hydrachnids", and described several new or rare species. But his greatest accomplishment was his joint authorship with Soar of the Ray Society's "British Hydracarina", the three volumes of which appeared in 1925, 1927 and 1928, and the synonymy and detailed descriptions in which were mainly the responsibility of Williamson, while Soar was entirely responsible for the skilled and beautiful illustrations.

Like Soar, Williamson was "an ardent field worker and an accomplished microscopist", a shy and modest man, who, although ill-health clouded his latter years, remained interested in his books-for he was an omnivorous reader-and in his water-mites until his last illness. He died in Edinburgh on December 19, 1950, at the age of eighty-one, his wife having predeceased him by a few months.

JAMES RITCHIH

\section{Mr. H. Y. Oldham}

HeNRY YULE OLDHAM was the son of Thomas Oldham, F.R.S., sometime director of the Geological Survey of India, and was educated at Rugby and at Jesus College, Oxford. After taking his degree he was for a time tutor to the Duc d'Orleans, and was always proud of the memory. He studied for a time in Paris, and, after some years of experience as an assistant master, first at the Hulme Grammar School in Manchester, then at Harrow (where Mr. Winston Churchill had been among his pupils), he spent a year of advanced study in geography in the University of Berlin.

In $1892 \mathrm{Mr}$. Oldham became a lecturer at Owens College, Manchester, and in the following year took up the lectureship created by the Royal Geographical Society for the encouragement of geographical studies at Cambridge. This he held with success for five years, after which he was promoted to the readership, which he held for ten years, from 1898. until 1908.

Mr. Oldham's death on March 14, at the ripe age of eighty-eight, breaks a link with the days when geography was not regarded generally as a scientific study, and when very little was done in schools or at the universities to foster interest. There are probably very few now living who remember Oldham in his prime, the pioneer whose enthusiasm drew large audiences, not so much at Cambridge as in the great manufacturing towns of the north of England, where his discourse-racy, anecdotal, scarcely perhaps by modern standards systematic enough to pass as academic-kindled an interest in such mysteries as the measurement of the curvature of the earth, and still keener interest in the story of the sailors and explorers who opened up the New World by their curiosity and courage. Oldham loved those tales, and had the natural and infectious eloquence which kindled the imagination of his hearers. This pioneer work, more than the papers he contributed occasion. ally to a learned journal, gave him his best title to remembrance as a geographer.

At Cambridge, Oldham is best remembered as the founder and for many years the 'Commodore' of a highly successful undergraduate oruising club. Many young men owed to him their love of sailing and of ships, and he was happy in the thought that in the First World War so many young men in the Navy did good service as the representatives of the cruising club which had been his and their delight in peacetime. There was no guile in Oldham. His was a gentle, friendly nature, and many of the younger generation at King's College, where he resided as a member of the High Table for just half a century, though they know little or nothing of his pioneer work for geography, will long remember him with warm affection. J. T. SHEPPARD

\section{Dr. Helmuth Lissner}

Dr. H. Lissner died at Haifa on February 15 of heart disease, and his passing came as a profound shock to his many friends in Great Britain, who admired his work as a fishery scientist and who loved him as a companion.

Lissner was born at Thorn in Prussia in December 1895. In 1916 he entered the University of Leipzig to study biology and natural history, and in 1920 he was employed at the biological station at Heligoland. In the following year he became assistant to Prof. Meisenheimer at Leipzig, and in 1922 he took the degree of doctor of philosophy and then joined Prof. Ehrenbaum, as assistant, in the Deutsche Wissenschaftliche Kommission für Meeresforschung in Hamburg.

There Lissner began his real fishery work, most of which was concerned with the study of the great German herring fishery, both from the biological and commercial points of view. Between 1922 and 1933 he published many papers on his subject, and ho was rapidly becoming an accepted expert in fishery science when the upheavals of the Third Reich forced him to leave Germany and go to England.

From February to November 1934 he worked at the Laboratory of the Marine Biological Association at Plymouth; then he took up an appointment with the Turkish Government in Istanbul. On the term. ination of this contract he went to the Institute of Marine Biology at Rovigno, but again left just before Italy entered the War. His next move was to the Philippines, where his brother was living, and once again he began work at a fisheries institute there, but he did not wish to stay after the War when he was offered a permanent post in fisheries.

Lissner finally settled in Palestine, where he succeeded, amid countless difficulties, in establishing a new Fisheries Institute with several departments, but he did not live to see the programme completed. His last wish was to be buried at Cresarea near the site of the new Institute.

W. C. HODGSON

WE regret to announce the death of Prof. A. Sommerfeld, For.Mem.R.S., sometime professor of theoretical physics in the University of Munich, which occurred on April 26. 